\title{
Effects of 2 liquid feeding rates over the first 3 months of life on whole-body energy metabolism and energy use efficiency of dairy calves up to 5 months
}

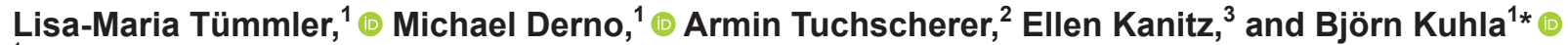 \\ ${ }^{1}$ Institute of Nutritional Physiology "Oskar Kellner," Leibniz Institute for Farm Animal Biology (FBN), Wilhelm-Stahl-Allee 1, 18196 Dummerstorf, \\ Germany \\ ${ }^{2}$ Institute of Genetics and Biometry, Leibniz Institute for Farm Animal Biology (FBN), 18196 Dummerstorf, Germany \\ ${ }^{3}$ Institute of Behavioural Physiology, Leibniz Institute for Farm Animal Biology (FBN), Wilhelm-Stahl-Allee 1, 18196 Dummerstorf, Germany
}

\section{ABSTRACT}

Intensified milk replacer (MR) feeding in calves has nutritional long-term effects and is suggested to increase milk production later in life. However, the underlying mechanisms are not completely understood. The aim of our study was to investigate whether MR feeding intensity has long-term effects on energy metabolism and energy use efficiency of dairy calves. Newborn female Holstein calves $(\mathrm{n}=28)$ were randomly assigned to 2 liquid feeding groups offered daily either $10 \%$ of body weight (BW) colostrum followed by $10 \%$ of $\mathrm{BW}$ MR (10\%-MR) or $12 \%$ of BW colostrum followed by $20 \%$ of BW MR (20\%-MR). Calves were housed individually. Weaning was completed by the end of wk 12. Hay and calf starter were fed from d 1 until the end of wk 14 and 16 , respectively. A total mixed ration was fed from wk 11 onward, and the metabolizable energy intake (MEI) was determined daily. Energy metabolism of calves was measured in respiratory chambers before weaning in wk 6 and 9 , and after weaning in wk 14 and 22 . The $\mathrm{MEI} / \mathrm{BW}^{0.75}$ was higher before weaning but lower during and shortly after weaning in $20 \%$-MR calves. During the preweaning period, the $20 \%$-MR animals had higher average daily gain, BW, back fat thickness and muscle diameter, but lower plasma $\beta$-hydroxybutyrate concentrations. The group difference in average daily gain ceased in wk 9, differences in back fat thickness and muscle diameter ceased after weaning, whereas difference in $\mathrm{BW}^{0.75}$ persisted until wk 23. The energy conversion ratio (BW gain/MEI) was not different before weaning, but was lower during and after weaning in 20\%-MR calves. The higher MEI and $\mathrm{BW}^{0.75}$ in $20 \%$ MR calves resulted in higher heat production (HP), as well as in higher carbohydrate oxidation (COX) and fat

Received February 10, 2021.

Accepted April 29, 2021.

*Corresponding author: b.kuhla@fbn-dummerstorf.de oxidation during the preweaning period. Gas exchange variables normalized to $\mathrm{BW}^{0.75}$ or MEI differed between groups only during preweaning. The energy balance was lower in 10\%-MR calves in wk 6 and 9. The $\mathrm{HP} / \mathrm{BW}^{0.75}$ and $\mathrm{COX} / \mathrm{BW}^{0.75}$ were higher, whereas $\mathrm{HP} / \mathrm{MEI}$ was lower in $20 \%$-MR calves in wk 6 . When normalized to $\mathrm{BW}^{0.75}$ and MEI, HP in wk 6 and 9, and COX in wk 9 was lower in 20\%-MR calves. In conclusion, $20 \%$-MR calves showed greater efficiency estimates preweaning, but this effect did not occur after weaning, suggesting that energy use efficiency does not persist until later stages in life.

Key words: indirect calorimetry, carbohydrate oxidation, fat oxidation, heat production

\section{INTRODUCTION}

In the last 2 decades, advantages of milk and milk replacer (MR) feeding regimens at increased rates in dairy calf rearing were intensively investigated (Kertz et al., 2017). Elevated MR feeding intensities (MFI) do not only support calf growth but also animal welfare, organ development and health as summarized in the review by Hammon et al. (2020). Furthermore, there is growing evidence that early-life intensified milk or MR feeding, accelerating preweaning ADG of dairy calves, has positive effects on productive performance in later life. A meta-analysis revealed that calves receiving more nutrients from milk or MR had $429 \pm 106 \mathrm{~kg}$ higher milk production during first lactation, and every kilogram of preweaning ADG increased first-lactation milk yield by $1,551 \mathrm{~kg}$ (Soberon and Van Amburgh, 2013). Different mechanisms are proposed to be involved in this nutritional long-term effect, commonly referred to as metabolic imprinting. The mechanisms under discussion are the stimulation of the somatotropic axis as reviewed by Hammon et al. (2020), the enhanced growth and development of organs such as the mammary gland as proposed from a meta-analysis by Gelsinger et al. (2016), or the rumen as suggested 
from a study in calves fed MR with high $\mathrm{CP}$ content at a rate of approximately $2 \%$ of birth $\mathrm{BW}$ as solids relative to calves fed a conventional MR at $1.25 \%$ of birth BW as solids (Naeem et al., 2012). Furthermore, an elevated metabolic activity, for instance, in the omental adipose tissue was discussed in a study comparing MR feeding at a fixed amount of approximately $0.55 \mathrm{~kg}$ of $\mathrm{DM} / \mathrm{d}$ versus $0.06 \mathrm{~kg}$ of $\mathrm{DM} / \mathrm{d}$ per $\mathrm{kg}$ of metabolic BW $\left(\mathrm{BW}^{0.75}, \mathbf{m B W}\right)$, which corresponds to a supply of 0.82 to $1.65 \mathrm{~kg}$ of DM/d (Leal et al., 2018). Recent research based on a metabolomics approach revealed long-term altered plasma acylcarnitine pattern in calves fed MR restrictively at about $0.75 \mathrm{~kg}$ of $\mathrm{DM} / \mathrm{d}$ or ad libitum and suggests epigenetic effects resulting in adapted mitochondrial function and hence metabolic profiles of energy metabolism (Kenéz et al., 2018).

Yet, transient detrimental effects of an elevated MFI as reviewed by Khan et al. (2011b) include reduced solid feed (SF) intake and digestibility of SF, delayed rumen development, and declining growth rates around weaning. To counter these difficulties, feeding elevated amounts of MR solids up to approximately 1.14 to 1.35 $\mathrm{kg} / \mathrm{d}$ and prolonged MR feeding (Eckert et al., 2015; Meale et al., 2015; Schwarzkopf et al., 2019), as well as gradual versus abrupt weaning (Steele et al., 2017) or versus weaning over a short period (Klopp et al., 2019) may overcome the aforementioned issues.

Methods to assess energy efficiency in calves include indirect calorimetry, which has been shown a suitable method for assessing energy efficiency in preweaned heifer calves (Leão et al., 2018) and dairy cows (Derno et al., 2019). Furthermore, the energy conversion ratio (ECR), defined as BW gain divided by ME intake (MEI), can be used as an indicator. However, the results reported for the effect of MFI on ECR so far are quite controversial. van Niekerk et al. (2020) on the one hand reported no differences in energy use efficiency during the preweaning period, but energy efficiency was compromised postweaning from wk 9 to 16 in calves fed MR up to 1.39 versus $0.7 \mathrm{~kg}$ of $\mathrm{DM} / \mathrm{d}$. Hu et al. (2019), on the other hand, observed a reduced energy use efficiency preweaning and a reduced gain/DMI ratio postweaning in calves fed MR at 0.96 compared with 0.66 $\mathrm{kg}$ of DM/d, whereas Chapman et al. (2017) found no effect of MFI when comparing MR feeding rates (on a DM basis) of $0.45 \mathrm{~kg} / \mathrm{d}$ of a conventional MR and 0.89 $\mathrm{kg} / \mathrm{d}$ of a moderately high $\mathrm{CP}$ content MR in pre-, peri, or postweaning periods. These controversial outcomes could be owed to differences in management, feeding, and weaning periods or the amounts and ingredients of offered feedstuffs.

Despite the growing numbers of studies investigating the relationship between early-life nutrition and pro- ductive performance in later life, the underlying physiological mechanisms are still not fully understood. The aim of the present study was to evaluate the metabolic efficiency of calves fed $20 \%$ of BW for a prolonged period of $12 \mathrm{wk}$, combined with gradual weaning over $4 \mathrm{wk}$ relative to calves receiving $10 \%$ of $\mathrm{BW}$ MR. The high MFI level was chosen because the allowance of $20 \%$ of BW is close to the ad libitum intake level (Hammon et al., 2020), and the prolonged feeding combined with gradual weaning was applied to fully reap the benefits of elevated MFI. The lower MFI level corresponds to the conventional dairy calf rearing system aiming to stimulate early starter intake and confining growth rate decline around weaning (Khan et al., 2011b). To assess metabolic efficiency, ECR was determined by 5 mo of age and indirect calorimetry was used 2 times before and 2 times after weaning. Because indirect calorimetry assesses only the net disappearance of substrates but does not consider metabolic intermediates (Simonson and DeFronzo, 1990), concentrations of plasma metabolites reflecting the intermediary metabolism were additionally analyzed. We hypothesized that calves fed an elevated MFI have the physiological potential for an increased metabolic efficiency, particularly involving an increased utilization efficiency of dietary fats and carbohydrates due to greater organ sizes and growth. We further hypothesized that a higher metabolic efficiency of calves receiving an increased MFI is accompanied with less energy loss, particularly heat, and that this effect is maintained in the postweaning period.

\section{MATERIALS AND METHODS}

\section{Animals, Experimental Design, and Diets}

All experimental procedures were in accordance with the German Animal Welfare Act and approved by the local ethics committee of the state government in Mecklenburg-West Pomerania, Germany, (Landesamt für Landwirtschaft, Lebensmittelsicherheit und Fischerei Mecklenburg-Vorpommern; approval No. 7221.3-1.1-009/16). The experiment was carried out at the Leibniz Institute for Farm Animal Biology (FBN), Dummerstorf, Germany. The 28 female newborn Holstein calves were acquired from the FBN herd and 2 dairy farms nearby. Calves were separated from their dams immediately after birth and moved to the calf barn at FBN without prior colostrum feeding. After weighing, the animals were housed in individual pens with wood shaving bedding and free access to water.

The calves were randomly assigned to 1 of $2 \mathrm{MR}$ feeding groups that consisted of being fed MR at a rate of either 10\% (10\%-MR; $\mathrm{n}=14)$ or 20\% (20\%-MR; 
$\mathrm{n}=14)$ of BW/d after $2.5 \mathrm{~d}$ of colostrum feeding. The colostrum feeding rate was $10 \%$ of BW for the $10 \%$-MR group and $12 \%$ of $\mathrm{BW}$ for the $20 \%$-MR group. At wk $3(18.4 \mathrm{~d} \pm 0.8)$, a permanent rumen cannula $(3.5 \mathrm{~cm}$ o.d.) was implanted in half of the animals of each feeding group. The experimental monitoring lasted until the end of wk 23. All authors were aware of the group allocation at all stages of the experiment.

Colostrum. Calves were fed colostrum with teat buckets for 5 meals during the first $2.5 \mathrm{~d}$ of life. During the first $2 \mathrm{~d}$, the 10\%-MR group was offered colostrum at a rate of $10 \%$ of birth weight daily ( 2 feedings/d, $5 \%$ of birth weight/meal) and the $20 \%$-MR group at a rate of $12 \%$ of birth weight daily ( 2 feedings/d, $6 \%$ of birth weight/meal). On d 3, the 10\%-MR group was offered $5 \%$ of birth weight in colostrum (first meal) and $5 \%$ of birth weight in MR (second meal). The 20\%-MR group was offered $7 \%$ of birth weight in colostrum (first meal) and $7 \%$ of birth weight in MR (second meal). In total, the $10 \%$-MR calves consumed $10.3 \pm 0.3 \mathrm{~L}$ of colostrum, whereas the 20\%-MR calves consumed 12.4 \pm 0.6 L. Colostrum was purchased from foreign farms from which no calves in this study originated and was provided for all animals from 3 pools (1 pool each for meals 1 and 2, meals 3 and 4, and meal 5), stored in aliquots at $-20^{\circ} \mathrm{C}$.

The first meal was fed immediately after arrival at the experimental calf barn, within 2 to $8 \mathrm{~h}$ after birth. The second meal was fed $4 \mathrm{~h}$ later at the earliest. All calves fed the first colostrum meal before $2000 \mathrm{~h}$ received the second meal on the same day, whereas calves fed the first meal after $2000 \mathrm{~h}$ received only one feeding on the arrival day. Subsequent colostrum meals were fed between 0630 and $0730 \mathrm{~h}$ and 1730 and 1830 h. In cases of residual colostrum, calves were offered the remaining amount in between the official feeding times.

Milk Replacer. After the colostrum feeding period, calves were provided with MR (BERGIN Milch LC 50, Bergophor Futtermittelfabrik Dr. Berger GmbH \& Co. KG; 140 g of powder $/ \mathrm{kg}$; Supplemental Table S1, https: //doi.org/10.5281/zenodo.4881616) by an automated calf feeder (Kälbermama LifeStart, Urban $\mathrm{GmbH}$ \& Co. KG). The liquid MR feeding rate at 10 and $20 \%$ of BW corresponds on the DM basis to 1.33 and $2.66 \%$ of BW, respectively. The allotted MR amount was adjusted weekly according to $\mathrm{BW}$ and was provided in 4 equal portions per day. After wk 6, the number of portions offered to the $20 \%$-MR calves was increased to 6 . Access to MR feeding was permanently available, except for the automatic daily cleaning times of the feeder from 0230 to $0500 \mathrm{~h}$. From wk 9 to the end of wk 10 , the MR feeding rate of the $20 \%$-MR group was gradually reduced to $10 \%$ of BW. Gradual weaning for both feeding groups was carried out from wk 11 to the end of wk 12.

Solid Feed. Long-stemmed grass hay was offered for ad libitum intake from d 1 until the end of wk 14. Pelleted starter was offered for ad libitum intake from $\mathrm{d}$ 1 until the end of wk 12. Thereafter, the allowance of starter was limited to $2 \mathrm{~kg} / \mathrm{d}$ in wk 13 and 14 and was gradually reduced to $0 \mathrm{~kg}$ in wk 15 and 16 . A TMR (Supplemental Table S2, https://doi.org/10.5281/ zenodo.4881616) was fed for ad libitum intake from wk 11 onwards. Intakes of starter, hay, and TMR were determined daily by manually weighing the offered feed and residual on the following day. Feed intake data were previously published (Tümmler et al., 2020).

Feed Sampling, Analyses, and ME Content Calculations. Samples of hay, starter, and MR powder were collected from every batch. The TMR samples were taken weekly for DM and for chemical analyses when animals were housed in the respiration chambers in wh 14 and 22. For the determination of DM content, samples were dried at $60^{\circ} \mathrm{C}$ for $24 \mathrm{~h}$ and subsequently at $103^{\circ} \mathrm{C}$ for $4 \mathrm{~h}$. Nutrient compositions were analyzed by the accredited service laboratory of Landwirtschaftliche Untersuchungs und Forschungsanstalt der LMS Agrarberatung GmbH (LUFA) and are presented in Supplemental Table S1.

For calculation of the ME content the recommendations of the German Society of Nutrition Physiology were used for hay (GfE, 2008), starter (GfE, 2009) and TMR (GfE, 2004). The ME content of MR was calculated following NRC (2001). Neonatal diarrhea occurring from wk 1 to 3 was treated with an oral electrolyte solution (Effydral, Zoetis) in addition to MR feeding, but its energy content was not considered in the calculation of MEI. Weekly means were calculated from daily MEI.

Body Measurements. The BW was measured weekly and $\mathrm{mBW}$ was calculated as $\mathrm{mBW}=\mathrm{BW}^{0.75}$. The ADG was calculated as weekly BW gain divided by 7 . Ultrasonic measurements were performed every 2 wk, starting in wk 3 or 4 , depending on the birth date of calves. Designated areas for ultrasonic measurements were clipped. Back fat thickness (BFT) was determined in the sacral region according to Schröder and Staufenbiel (2006) and the longissimus dorsi muscle diameter (MD) was determined according to Bruckmaier et al. (1998) at the fifth loin vertebra, using an ultrasonic scanner (Titan Ultrasound System, Sonosite Inc.), equipped with a linear probe (L52/10-5 MHz Transducer, Sonosite Inc.).

Energy Conversion Ratio. The ECR was calculated on a weekly basis and over the whole preweaning 
(wk 2-8), weaning (wk 9-12), and postweaning (wk 13-22) periods as BW gain (kg) divided by MEI (MJ).

\section{Indirect Calorimetry}

Whole-body energy metabolism of individual calves was assessed 2 times before and 2 times after weaning in open-circuit respiration chambers as described by Derno et al. (2009). Gas exchange measurements were undertaken for 2 consecutive 24 h-periods in wk 6 (36.6 $\mathrm{d} \pm 0.5)$, wk $9(58.4 \mathrm{~d} \pm 0.5)$, wk 14 (92.9 d \pm 0.7$)$, and wk $22(149.8 \mathrm{~d} \pm 0.6)$. Calves were moved into the respiration chamber 12 to $16 \mathrm{~h}$ before measurement start to allow for adaption and gas exchange equilibration. The calves were provided with free access to water and kept at thermoneutral conditions at $18^{\circ} \mathrm{C}$ in wk 6 and at $15^{\circ} \mathrm{C}$ in wk 9,14 , and 22 . In wk 6 , the MR for both groups was bucket-fed in 3 equal portions at 0700 , 1300, and $1800 \mathrm{~h}$. In wk 9, the same feeding schedule was applied except the 20\%-MR animals received 4 equal portions with the additional feeding occurring at $1000 \mathrm{~h}$. The SF intake was determined by manual weighing, and TMR intake by an electronic registration device (PAARI).

Mean $\mathrm{CO}_{2}$ recovery rates of the 4 chambers were $100.9 \pm 0.7 \%, 99.8 \pm 0.3 \%, 99.5 \pm 0.4 \%$, and 100.7 $\pm 0.4 \%$. Concentrations of $\mathrm{CO}_{2}$ and $\mathrm{CH}_{4}$ were measured by infrared absorption (SIDOR, Sick AG), and $\mathrm{O}_{2}$ concentrations were measured paramagnetically (SIDOR, Sick AG) every 6 min. The airflow through the chamber was approximately $10 \mathrm{~m}^{3} / \mathrm{h}$ and was measured by a differential pressure-type $\mathrm{V}$ cone flow meter (McCrometer). Physical activity was measured by a modified infrared-based motion detector (IS 120, Steinel). Staff wore face masks connected via flexible tubing to ambient air during animal care and cleaning to prevent interference with the animal's gas exchange. The BW was measured right before and after stay in the chamber and the mean was used to calculate $\mathrm{mBW}$. Due to technical problems or health issues of the calves, 3 gas exchange measurements in wk 6 and one measurement each in wk 9 and 14 were excluded from statistical analysis. In 2 further cases, one each in wk 14 and 22, only the value of the first $24 \mathrm{~h}$-period was used.

For the following calculations, data were used as mean of both $24 \mathrm{~h}$-periods, except for the 2 cases when only the value of the first $24 \mathrm{~h}$-period was available. Total $\mathrm{CO}_{2}$ production $\left(\mathbf{C O}_{2}\right.$ total $)$ is the sum of fermentative $\mathrm{CO}_{2}\left(\mathbf{C O}_{2}\right.$ ferm $)$ and metabolic $\mathrm{CO}_{2}\left(\mathbf{C O}_{2}\right.$ metab $)$, and $\mathrm{CO}_{2}$ ferm was calculated according to Chwalibog et al. (1996) as $\mathrm{CO}_{2 \text { ferm }}(\mathrm{L})=1.7 \times \mathrm{CH}_{4}(\mathrm{~L})$. Consequently, $\mathrm{CO}_{2 \text { metab }}$ can be calculated by subtracting $\mathrm{CO}_{2}$ ferm from
$\mathrm{CO}_{2}$ total (Derno et al., 2013) and the metabolic respiratory quotient $\left(\mathbf{R Q}_{\text {metab }}\right)$ was calculated as $\mathrm{CO}_{2}$ metab (L) $/ \mathrm{O}_{2}$ (L) (Derno et al., 2019). The urinary N excretion $\left(\mathbf{N}_{\mathbf{u}}\right)$ was not measured but estimated based on the BW of calves according to Jentsch et al. (1996): $\mathrm{N}_{\mathrm{u}}=$ $10 \mathrm{~g} / \mathrm{d}$ for $\mathrm{BW} \leq 43 \mathrm{~kg}, \mathrm{~N}_{\mathrm{u}}=12 \mathrm{~g} / \mathrm{d}$ for $\mathrm{BW} \leq 83 \mathrm{~kg}$, $\mathrm{N}_{\mathrm{u}}=20 \mathrm{~g} / \mathrm{d}$ for BW $\leq 120 \mathrm{~kg}$, and $\mathrm{N}_{\mathrm{u}}=25 \mathrm{~g} / \mathrm{d}$ for BW $>120 \mathrm{~kg}$. The potential error in the calculation of heat production (HP) through the estimation of urinal $\mathrm{N}$ excretion is relatively small as $\mathrm{N}$ excretion affects $\mathrm{HP}$ by an error smaller than 2\% (Simonson and DeFronzo, 1990). Daily HP was calculated according to Brouwer (1965):

$$
\begin{gathered}
\mathrm{HP}(\mathrm{kJ} / \mathrm{d})=16.18 \mathrm{O}_{2}(\mathrm{~L} / \mathrm{d})+5.02 \mathrm{CO}_{2} \text { total }(\mathrm{L} / \mathrm{d}) \\
-2.17 \mathrm{CH}_{4}(\mathrm{~L} / \mathrm{d})-5.99 \mathrm{~N}_{\mathrm{u}}(\mathrm{g} / \mathrm{d}) .
\end{gathered}
$$

The energy balance $(\mathbf{E B})$ was calculated as EB $(\mathrm{MJ} / \mathrm{d})$ $=\mathrm{HP}(\mathrm{MJ} / \mathrm{d})-\mathrm{MEI}(\mathrm{MJ} / \mathrm{d})$.

Net carbohydrate oxidation $(\mathbf{C O X})$ and net fat oxidation (FOX) were estimated by the following equations previously described by Derno et al. (2013):

$$
\begin{gathered}
\operatorname{COX}(\mathrm{g} / \mathrm{d})=4.57 \mathrm{CO}_{2} \text { metab }(\mathrm{L} / \mathrm{d}) \\
-3.23 \mathrm{O}_{2}(\mathrm{~L} / \mathrm{d})-2.60 \mathrm{~N}_{\mathrm{u}}(\mathrm{g} / \mathrm{d}) ; \\
\operatorname{FOX}(\mathrm{g} / \mathrm{d})=1.69 \mathrm{O}_{2}(\mathrm{~L} / \mathrm{d}) \\
-1.69 \mathrm{CO}_{2 \text { metab }}(\mathrm{L} / \mathrm{d})-2.03 \mathrm{~N}_{\mathrm{u}}(\mathrm{g} / \mathrm{d}) .
\end{gathered}
$$

\section{Blood Sampling and Plasma Metabolite Analyses}

Blood samples were collected before colostrum feeding on $\mathrm{d} 1(1 \mathrm{~d} \pm 0)$ and at the beginning of wk 2 $(7.8 \mathrm{~d} \pm 0.3), 3(15.2 \mathrm{~d} \pm 0.4), 5(28.5 \mathrm{~d} \pm 0.4), 7$ (42.7 d \pm 0.4$), 9(56.1 \mathrm{~d} \pm 0.5), 11(70.7 \mathrm{~d} \pm 0.5), 14$ $(91.0 \mathrm{~d} \pm 0.6), 18(120.3 \mathrm{~d} \pm 0.5)$, and $22(147.7 \mathrm{~d} \pm$ 0.6) from the jugular vein into $9-\mathrm{mL}$ monovettes with EDTA (catalog no. 02.267.001, Sarstedt). Samples were immediately placed on ice and subsequently centrifuged at $4^{\circ} \mathrm{C}$ for $20 \mathrm{~min}$ at $1,565 \times \mathrm{g}$. The obtained plasma was stored at $-20^{\circ} \mathrm{C}$ until analysis.

Plasma was analyzed spectrophotometrically by use of a semi-automatic analyzer (Abx Pentra 400, Horiba) and commercial kits for the concentrations of $\mathrm{BHB}$ (RB1007, Randox Laboratories), nonesterified fatty acids [NEFA; NEFA-HR(2), FUJIFILM Wako Chemicals Europe GmbH], triglycerides (TG; A11A01640, Horiba), glucose (A11A01667, Horiba), L-lactate (A11A01721, Horiba), albumin (A11A01664, Horiba), and urea (LT-UR 0010, Labor + Technik Eberhard Lehmann GmbH). 


\section{Saliva Sampling and Analyses}

Saliva samples were taken on $\mathrm{d} 4(3.7 \mathrm{~d} \pm 0.2)$ and at the beginning of wk $2(8.4 \mathrm{~d} \pm 0.2), 7(43.3 \mathrm{~d} \pm 0.4)$, and $14(91.3 \mathrm{~d} \pm 0.6)$. Samples were collected by placing a cloth swab ( $82 \%$ viscose, $18 \%$ polypropylene) into the mouth of the animal until the swab was soaked with saliva. The swab was inserted into a $50-\mathrm{mL}$ tube, fixed with the cap, and centrifuged at $4^{\circ} \mathrm{C}$ and $3,360 \times g$ for $30 \mathrm{~s}$. The swab was removed, and the obtained saliva centrifuged under the same conditions for a further 2 min. The saliva was snap-frozen in liquid nitrogen and stored at $-20^{\circ} \mathrm{C}$ until analysis. Salivary cortisol concentrations were measured with a commercially available enzyme immunoassay (DES6611, Demeditec Diagnostics $\mathrm{GmbH}$ ) according to the manufacturer specifications. The sensitivity of the assay was $0.06 \mathrm{ng} / \mathrm{mL}$, and the intra- and interassay coefficients of variation were 4.2 and $8.6 \%$, respectively.

\section{Statistical Analyses}

For the study design, a power analysis was performed to determine the sample size, considering HP as the primary outcome measure. Statistical analyses were conducted using the SAS software for Windows, version 9.4 (SAS Institute Inc.). A repeated measurement analyses of variance with the MIXED procedure was performed. The model included the fixed effects of MR feeding group (10\%-MR, 20\%-MR), cannula (cannulated, noncannulated), time, and all interactions with time as the repeated variable. The block diagonal residual covariance matrix was modeled as unstructured for all analyses. To allow statistical comparison of the ultrasonic measures, which were taken in 2-wk intervals, values from every 2 consecutive weeks were considered as one measurement (wk 3 and 4 as wk 3.5 and so forth). Least squares means (LSM) and respective standard errors (SE) were computed for the fixed effects and the Tukey-Kramer procedure was used to test pairwise differences between LSM. For partitioned analyses of the LSM for all interactions, the SLICE statement of the MIXED procedure was used.

The REG procedure was used to model a linear regression between weekly ECR as the dependent variable and BW as the independent variable for both MR feeding groups during the postweaning period. The slope and intercept of the 2 regression lines were compared with the MIXED procedure and an unstructured modeled covariance matrix, setting BW and MR feeding group as fixed effects. Effects and differences were considered significant at $P$-values $<0.05$. Results are presented as $\mathrm{LSM} \pm \mathrm{SE}$.

\section{RESULTS}

\section{Energy Intake, Conversion, and Growth}

The MEI increased over time in both feeding groups $\left(P_{\text {time }}<0.05\right)$ and was higher in $20 \%$-MR animals $\left(P_{\text {MR-rate }}>0.05\right)$ with the greatest differences occurring before weaning (Figure 1a). Similarly, MEI $/ \mathrm{mBW}$ was higher in 20\%-MR calves mainly preweaning $(P>0.05)$ and increased until wk 8 in $20 \%$-MR and wk 10 in $10 \%$-MR animals $\left(P_{\text {time }}<0.05\right.$; Figure $\left.1 b\right)$. Thereafter, $\mathrm{MEI} / \mathrm{mBW}$ of $20 \%$-MR animals temporarily dropped and was lower in wk 11 and $13(P<0.05)$, and tended to be lower in wk $14(P<0.10$; Figure $1 \mathrm{~b})$ than $10 \%$ MR animals. From wk 15 onward, MEI $/ \mathrm{mBW}$ was comparable between groups. The ADG also increased over time in both groups, particularly before weaning $\left(P_{\text {time }}<0.05\right.$; Figure 1c), and was higher in $20 \%$-MR calves from wk 1 to $8(P<0.05$; Figure $1 \mathrm{c})$. The weekly ECR neither differed between MR feeding groups nor changed over time (Figure 1d). Comparing the ECR between groups during single feeding periods revealed similar levels before weaning (wk 2 to 8 ) but higher levels in 10\%-MR relative to $20 \%$-MR calves during the weaning (wk 9 to 12) and postweaning (wk 13 to 22) periods $(P<0.05$; Table 1$)$.

To examine if weekly ECR and $\mathrm{mBW}$ have similar linear equations during the postweaning period, linear regression analysis was performed. The best fit for the $10 \%$-MR group was: $\mathrm{ECR}=0.0594-0.000792 \times$ mBW ( $P$-value $\left.<0.001 ; \mathrm{R}^{2}=0.20\right)$ and for the $20 \%$-MR group: $\mathrm{ECR}=0.0616-0.000815 \times \mathrm{mBW}(P$-value $\left.<0.001 ; \mathrm{R}^{2}=0.21\right)$. The comparison of the 2 regression lines revealed no difference in slope $(P=0.90)$ and intercept $(P=0.79)$.

\section{Body Weight and Condition}

Metabolic BW, BFT, and MD increased in both MR feeding groups over the course of the experimental period $\left(P_{\text {time }}<0.05\right)$, and was higher in all variables in $20 \%$-MR compared with $10 \%$-MR calves $\left(P_{\text {MR-rate }}<\right.$ 0.05; Figure 2). However, differences in MD between groups ceased from wk 17.5 until the end of the study (Figure 2c).

\section{Metabolic Heat Production, Carbohydrates, and Fat Oxidation}

The results from measurements in respiration chambers are presented in Table 2. The MEI, mBW, and $\mathrm{MEI} / \mathrm{mBW}$, measured during respiration chamber experiments essentially correspond with data collected in 
Table 1. Energy conversion ratio (BW gain per ME intake; ECR) during the preweaning (wk 2-8), weaning (wk 9-12), and postweaning (wk 13-22) periods of calves fed milk replacer (MR) at a rate of either $10 \%(10 \%$-MR) or $20 \%(20 \%-\mathrm{MR})$ of $\mathrm{BW}$

\begin{tabular}{lcccc}
\hline & \multicolumn{2}{c}{ ECR $(\mathrm{g} / \mathrm{MJ})$} & & \\
\cline { 2 - 3 } Period & $10 \%$-MR & $20 \%$-MR & \multirow{2}{*}{ SE } & $P$-value \\
\hline Wk 2-8 & 34.0 & 33.3 & 1.06 & 0.67 \\
Wk 9-12 & 35.4 & 30.6 & 1.23 & $<0.05$ \\
Wk 13-22 & 23.8 & 20.9 & 0.42 & $<0.001$ \\
\hline
\end{tabular}

${ }^{1} P$-values from SLICE test. Fixed effects: $P_{\text {MR-rate }}<0.05, P_{\text {time }}<$ $0.001, P_{\mathrm{MR} \text {-ratextime }}=0.21$. $P$-values of the fixed effects of cannula MR-rate $\times$ cannula, and MR-rate $\times$ cannula $\times$ time are presented in Supplemental Table S4 (https://doi.org/10.5281/zenodo.4881616).

the barn. The $\mathrm{RQ}_{\text {metab }}$ increased from wk 6 to $22\left(P_{\text {time }}\right.$ $<0.05)$, but did not differ between the groups at any measured time. Similarly, physical activity increased over the course of the experimental period $\left(P_{\text {time }}<\right.$ 0.05 ) and tended to be higher in 20\%-MR than $10 \%$ MR animals in wk $6(P<0.10)$ but not at other time points. Total HP increased with growth $\left(P_{\text {time }}<0.05\right)$ and levels were higher in 20\%-MR than $10 \%$-MR calves for all measurement periods $(P<0.05)$. When HP was normalized to $\mathrm{mBW}$, values were still greater for the $20 \%$-MR compared with $10 \%$-MR group in wk $6(P<$ $0.05)$ but converge with progressing time $\left(P_{\text {MR-ratextime }}<\right.$ 0.05). Conversely, normalization of HP to MEI revealed higher values in $10 \%$-MR than $20 \%$-MR counterparts in wk $6(P<0.05)$. When HP was normalized for differences in $\mathrm{mBW}$ and MEI, values decreased over time $\left(P_{\text {time }}<0.05\right)$, with $20 \%$-MR animals exhibiting lower values than $10 \%$-MR fed calves $\left(P_{\text {MR-rate }}<0.05\right)$.

Total COX, as well as COX/mBW and COX/MEI increased over the course of the study $\left(P_{\text {time }}<0.05\right)$. Although COX was greater, COX normalized to (mBW $\times$ MEI) was lower in 20\%-MR than $10 \%$-MR calves $\left(P_{\mathrm{MR}-\text { rate }}<0.05\right)$. In addition, $\mathrm{COX} / \mathrm{mBW}$ was higher in $20 \%$-MR animals only in wk $6(P<0.05)$. On the contrary, total FOX did not change over time, but was higher preweaning in wk 9 in $20 \%$-MR than $10 \%$-MR animals. Normalization of FOX for MEI, mBW, or (MEI $\times \mathrm{mBW}$ ) did not differ between MR feeding groups but
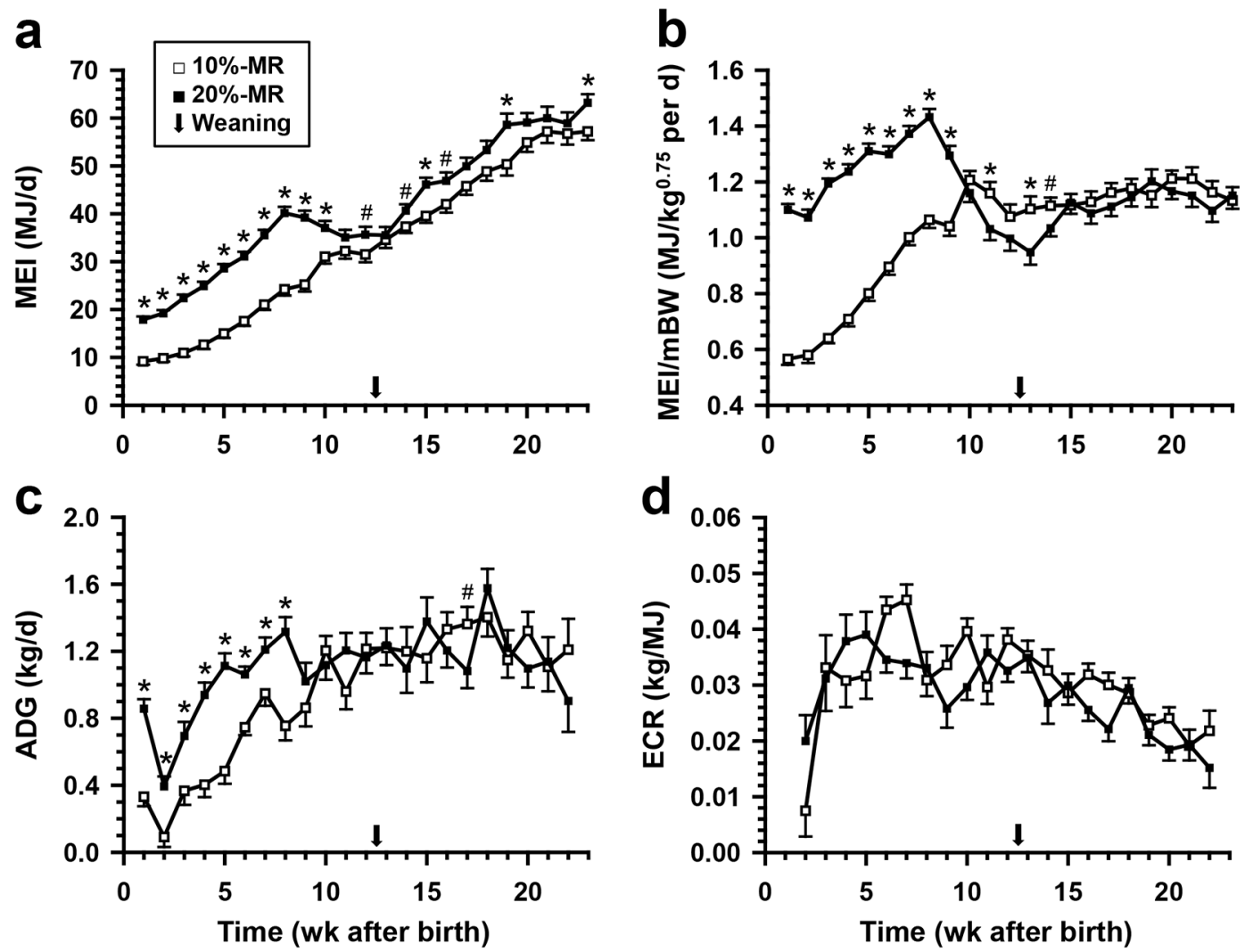

Figure 1. Average daily ME intake (MEI; a) and average daily MEI/metabolic BW (mBW; b) starting from d 4, ADG (c), and energy conversion ratio (ECR; BW gain/MEI; d) in calves fed milk replacer (MR) at a rate of either $10 \%(\square 10 \%$-MR) or $20 \%$ ( $\square 20 \%$-MR) of BW The arrows indicate completed weaning. Data are shown as LSM $\pm \mathrm{SE} ;{ }^{*} P<0.05, \# P<0.10$ (SLICE). (a-c) $P_{\text {MR-rate }}<0.001, P_{\text {time }}<0.001$, $P_{\text {MR-ratextime }}<0.001$. (d) $P_{\text {MR-rate }}=0.23, P_{\text {time }}=0.11, P_{\text {MR-ratextime }}=0.23$. $P$-values of the fixed effects of cannula, MR-rate $\times$ cannula and MRrate $\times$ cannula $\times$ time are presented in Supplemental Table S3 (https://doi.org/10.5281/zenodo.4881616). 

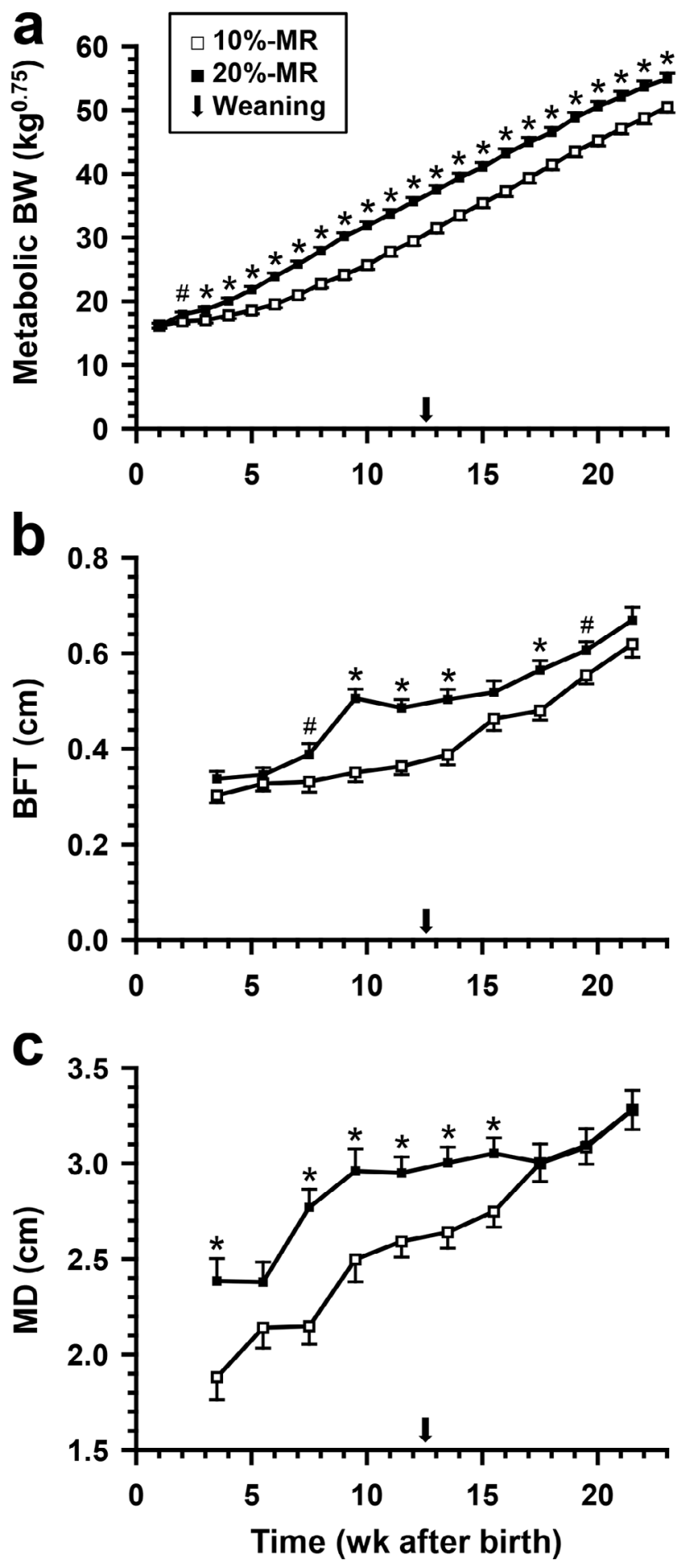

Figure 2. Metabolic BW (a), back fat thickness (BFT; b), and longissimus dorsi muscle diameter (MD; c) in calves fed milk replacer (MR) at a rate of either $10 \%$ ( $\square 10 \%$-MR) or $20 \%$ ( $20 \%$-MR) of BW. The arrows indicate completed weaning. Data are shown as LSM $\pm \mathrm{SE} ;{ }^{*} P<0.05, \# P<0.10$ (SLICE). (a) $P_{\mathrm{MR} \text {-rate }}<0.001, P_{\text {time }}$ $<0.001, P_{\text {MR-rate } \times \text { time }}<0.001$. (b) $P_{\text {MR-rate }}<0.001, P_{\text {time }}<0.001$, $P_{\text {MR-rate } \times \text { time }}<0.05$. (c) $P_{\text {MR-rate }}<0.05, P_{\text {time }}<0.001, P_{\text {MR-rate } \times \text { time }}<$ 0.05 . $P$-values of the fixed effects of cannula, MR-rate $\times$ cannula and MR-rate $\times$ cannula $\times$ time are presented in Supplemental Table S5 (https://doi.org/10.5281/zenodo.4881616). all changed over time $\left(P_{\text {time }}<0.05\right)$. The EB was lower in wk $6(P<0.05)$ and tended to be lower in wk $9(P$ $<0.10)$ in $10 \%$-MR than in $20 \%$-MR calves, but these group differences were not evident after weaning.

\section{Plasma and Salivary Metabolites}

Plasma glucose concentrations increased in both MR groups between $\mathrm{d} 1$ before first feeding and wk 2, but decreased between wk 9 and 14 during weaning $\left(P_{\text {time }}\right.$ $<0.05)$. Although we detected no overall differences in plasma glucose concentrations between groups, glucose concentration was higher in wk 7 before weaning and lower in wk 22 after weaning in 20\%-MR compared with $10 \%$-MR calves $(P<0.05$; Figure 3a). Plasma BHB levels increased in both groups during the entire experimental period $\left(P_{\text {time }}<0.05\right)$ but the increase was more pronounced in the $10 \%$-MR group, specifically preweaning. Thus, BHB concentrations were higher in $10 \%$-MR than $20 \%$-MR calves during the preweaning period $\left(P_{\text {MR-rate }}<0.05\right.$; Figure $\left.3 \mathrm{~b}\right)$. Plasma NEFA concentrations decreased remarkably from d 1 until wk 2 in calves at both MR rates $(P<0.05$; Figure 3c). The $20 \%$-MR group, however, exhibited a lower NEFA concentration in wk 2 but higher concentrations in wk 5 and 9 compared with $10 \%-\mathrm{MR}$ animals $(P<0.05$; Figure 3c). Plasma TG concentrations were higher in wk 2 , 3 , and 5 preweaning but lower in wk 18 in the $20 \%$-MR compared with $10 \%$-MR group $(P<0.05$; Figure $3 \mathrm{~d})$. Plasma urea concentrations decreased from d 1 to wk 2 $(P<0.05)$. The lowest urea concentration for $20 \%$-MR fed calves was reached at wk 2 , whereas the lowest urea concentration for 10\%-MR fed calves was not reached until wk 9 (Figure 4a). Accordingly, urea concentrations in the 10\%-MR group were higher in wk 2 and 5 but lower in wk 9 compared with 20\%-MR animals $(P<0.05)$. From wk 11 onward, urea concentrations increased in both MR groups to a maximum in wk 22. Plasma albumin concentrations steadily increased over time $\left(P_{\text {time }}<0.05\right.$; Figure $\left.4 \mathrm{~b}\right)$. Plasma L-lactate concentrations decreased sharply from d 1 to wk $2(P$ $<0.05)$ but levels of MR feeding groups did not differ over the experimental course (Figure 4c). Salivary cortisol concentration decreased between d 4 and wk $14\left(P_{\text {time }}<0.05\right)$ but did not differ between MR groups (Figure 5).

\section{DISCUSSION}

\section{Metabolizable Energy Intake and Growth Performance}

Due to the higher MFI, MEI/mBW and MEI were much greater from wk 1 until wk 9 and 10, respectively, 
Tümmler et al.: MILK REPLACER FEEDING AND ENERGY METABOLISM IN CALVES

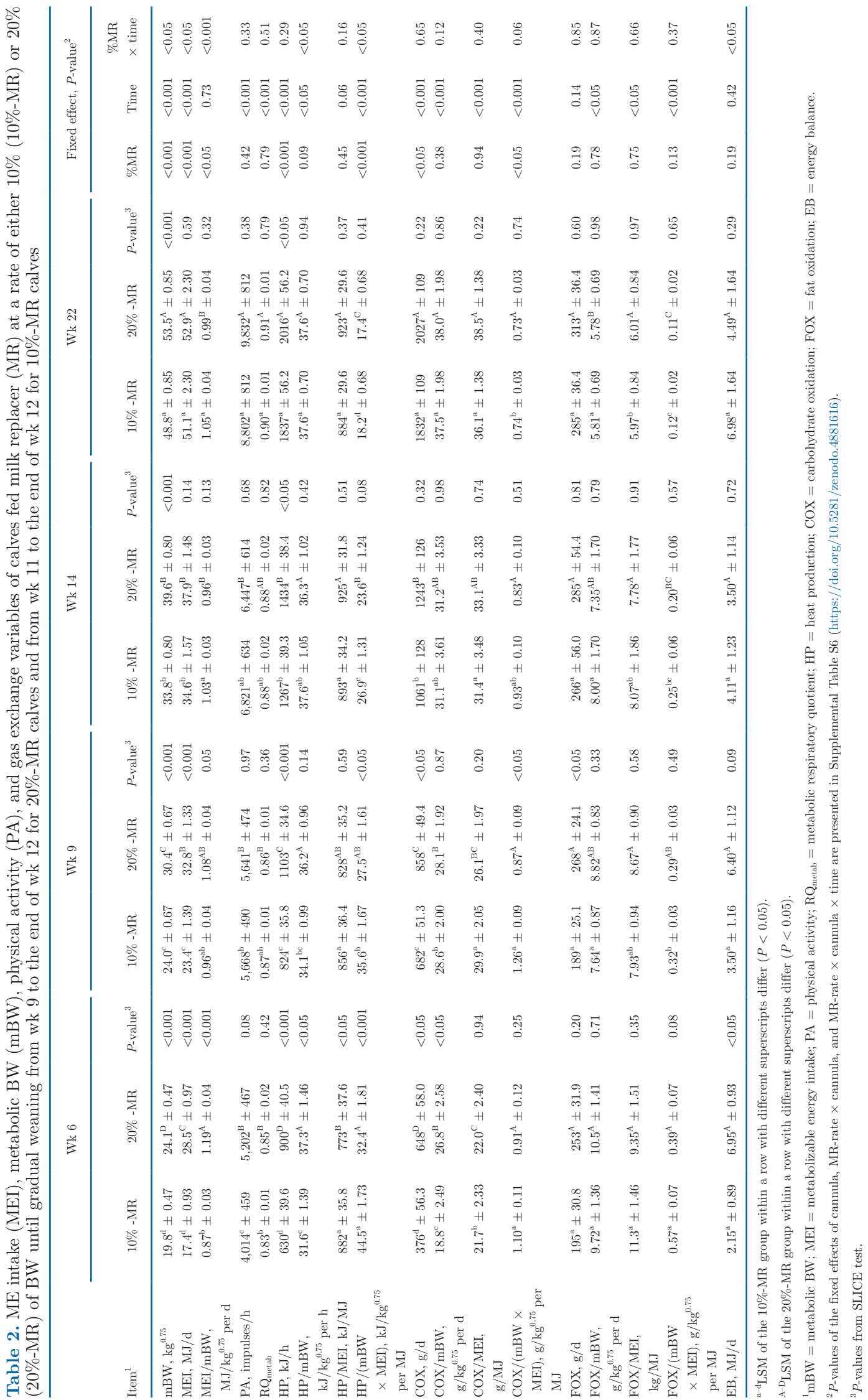



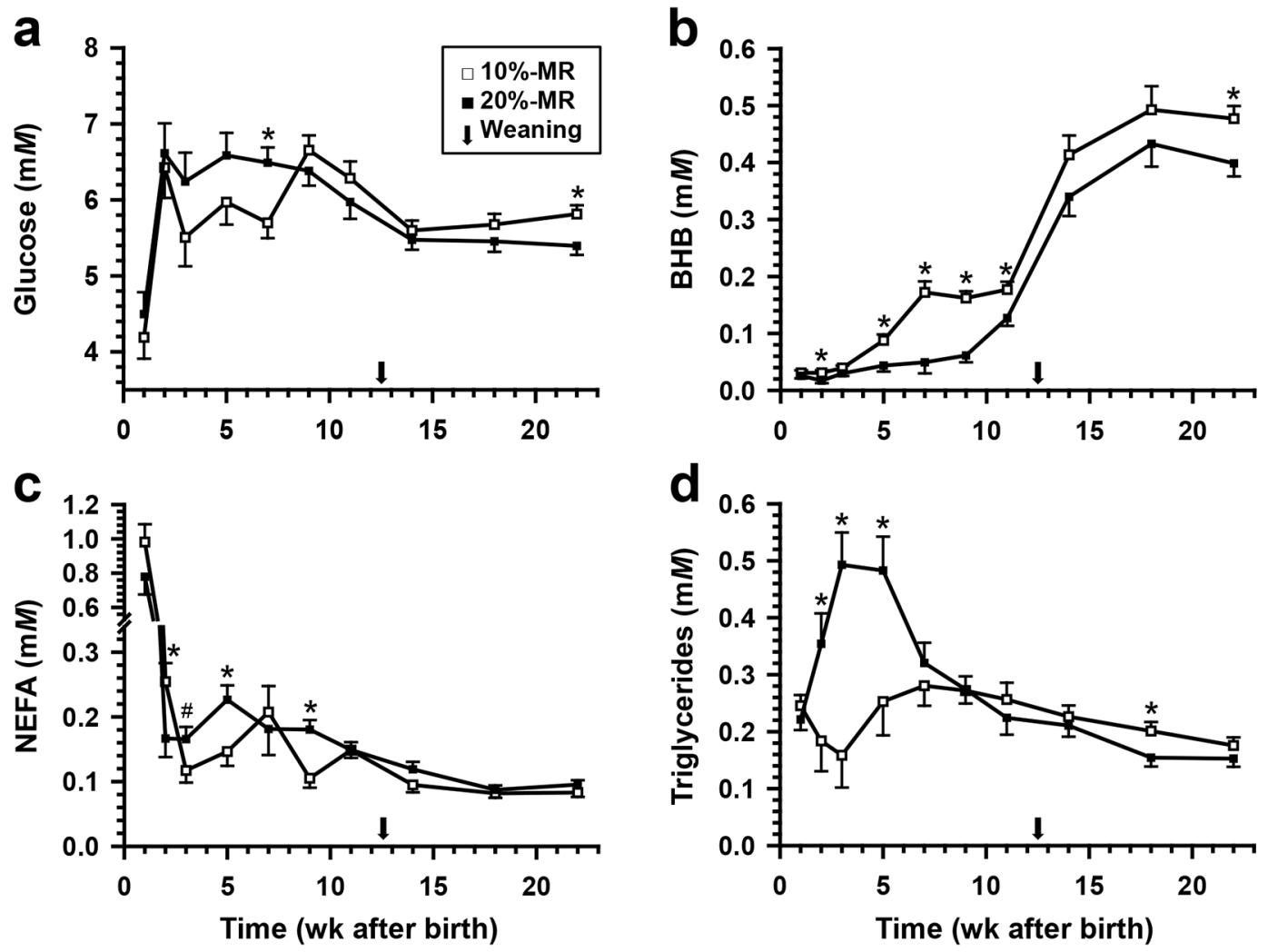

Figure 3. Blood plasma concentrations of glucose (a), BHB (b), nonesterified fatty acids (NEFA; c), and triglycerides (d) in calves fed milk replacer $(\mathrm{MR})$ at a rate of either $10 \%(\square 10 \%-\mathrm{MR})$ or $20 \%(\boldsymbol{\square} 20 \%$-MR) of BW. The arrows indicate completed weaning. Data are shown as $\mathrm{LSM} \pm \mathrm{SE} ;{ }^{*} P<0.05, \# P<0.10$ (SLICE). (a) $P_{\text {MR-rate }}=0.38, P_{\text {time }}<0.001, P_{\text {MR-ratextime }}<0.05$. (b) $P_{\text {MR-rate }}<0.001, P_{\text {time }}<0.001, P_{\text {MR-rate } x \text { time }}$ $<0.001$. (c) $P_{\text {MR-rate }}=0.72, P_{\text {time }}<0.001, P_{\text {MR-ratextime }}<0.001$. (d) $P_{\text {MR-rate }}<0.05, P_{\text {time }}<0.001, P_{\text {MR-ratextime }}<0.001$. The $P$-values of the fixed effects of cannula, MR-rate $\times$ cannula, and MR-rate $\times$ cannula $\times$ time are presented in Supplemental Table S7 (https://doi.org/10.5281/zenodo .4881616).

in $20 \%$-MR compared with $10 \%$-MR calves, amounting to a maximum difference of $15.9 \mathrm{MJ} / \mathrm{d}$ MEI in wk 8. The higher MEI and MEI/mBW reflect the overall improved energy and nutrient supply in $20 \%$-MR fed calves, thus providing the condition for a potential metabolic imprinting as proposed in the review by Soberon and Van Amburgh (2013). The lower MR intake in the 10\%-MR group lead to higher DMI of SF (hay, concentrate, and TMR) preweaning in wk 6 to 10, whereas postweaning DMI levels of SF were mostly higher in the 20\%-MR group (Tümmler et al., 2020). Although the $10 \%$-MR fed group revealed higher DMI of SF preweaning, which was similarly observed as a linear increase of forage intake with MR reduction (Broesder et al., 1990) or in a model for starter intake (Silva et al., 2019), this effect was not sufficient to compensate for the lower energy intake with MR in this group. Consideration must also be given to the fact that ME of SF might be overestimated because digestibility is lower in young calves and energy from starter is less metabolically available as predicted by NRC (2001) models
(Quigley et al., 2019). Therefore, the actual preweaning MEI in 10\%-MR calves might have been even lower than calculated herein. It is also important to note that MEI values were estimated based on German Society of Nutrition Physiology and National Research Council feeding recommendations and not measured, and thus may include some minor uncertainty.

Around weaning, on the other hand, the $\mathrm{MEI} / \mathrm{mBW}$ ratio decreased from wk 9 to 13 in the $20 \%$-MR group and even dropped below the levels of $10 \%$-MR counterparts. A comparable result was observed in the study by Chapman et al. (2016) demonstrating a decrease in DMI/BW approximately $1 \mathrm{wk}$ after weaning in calves fed preweaning a MR feeding rate (DM basis, varying fat contents) of $0.87 \mathrm{~kg} / \mathrm{d}$ of a $27 \% \mathrm{CP}$ content MR compared with counterparts fed $0.44 \mathrm{~kg} / \mathrm{d}$ of a $21 \%$ or $0.66 \mathrm{~kg} / \mathrm{d}$ of a $27 \% \mathrm{CP}$ content MR, demonstrating the difficulties of calves fed high MFI to adapt to the forced diet change during weaning. Relative to calves fed $10 \%$ of $\mathrm{BW} / \mathrm{d}$, calves offered milk ad libitum (Jasper and Weary, 2002) or up to $20 \%$ of BW (Khan et al., 2007b) 

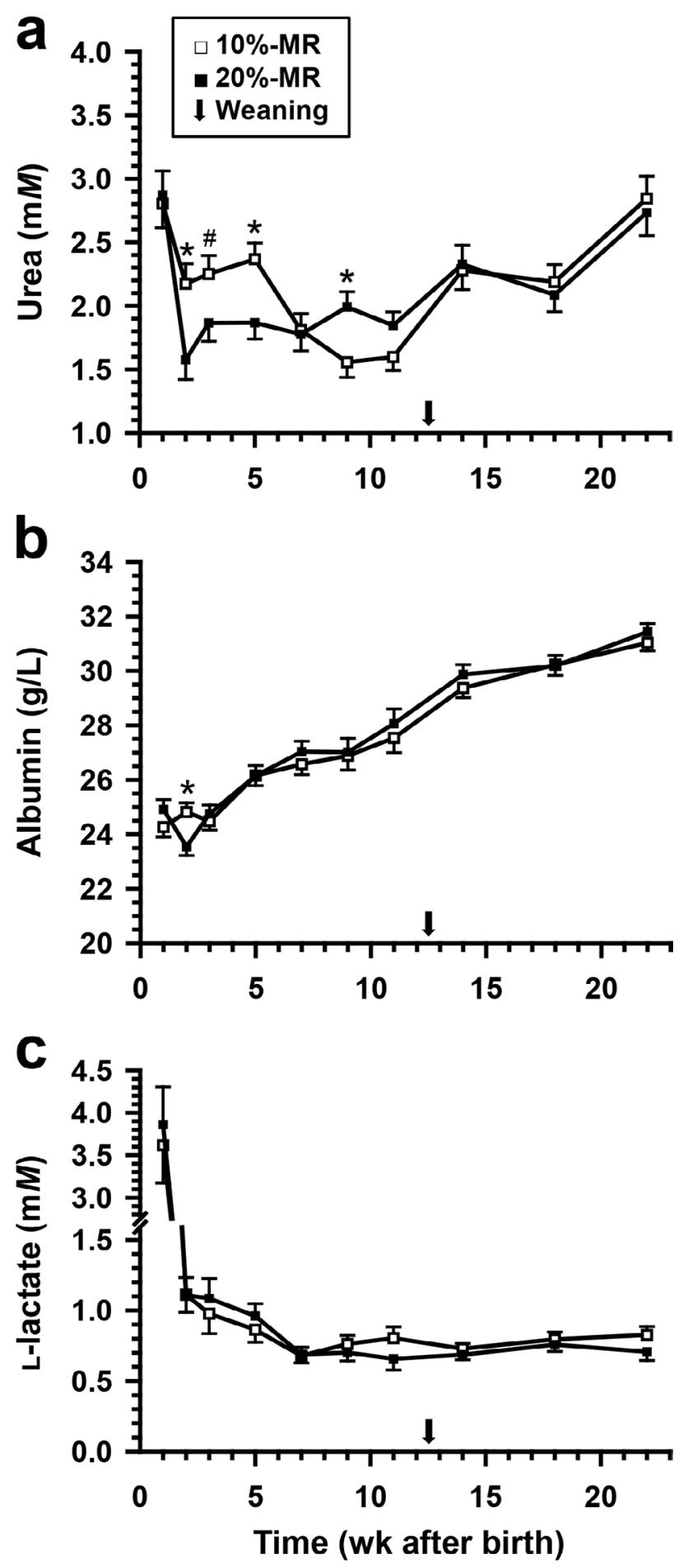

Figure 4. Blood plasma concentrations of urea (a), albumin (b), and L-lactate (c) in calves fed milk replacer (MR) at a rate of either $10 \%(\square 10 \%$-MR) or $20 \%(\square 20 \%$-MR) of BW. The arrows indicate completed weaning. Data are shown as $\mathrm{LSM} \pm \mathrm{SE} ;{ }^{*} P<0.05, \# P<$ 0.10 (SLICE). (a) $P_{\text {MR-rate }}=0.41, P_{\text {time }}<0.001, P_{\text {MR-rate } \times \text { time }}<0.05$. (b) $P_{\text {MR-rate }}=0.64, P_{\text {time }}<0.001, P_{\text {MR-ratextime }}<0.05$. (c) $P_{\text {MR-rate }}=$ $0.95, P_{\text {time }}<0.001, P_{\text {MR-ratextime }}=0.77$. $P$-values of the fixed effects of cannula, MR-rate $\times$ cannula and MR-rate $\times$ cannula $\times$ time are presented in Supplemental Table S8 (https://doi.org/10.5281/zenodo .4881616). had similar or showed even higher SF intake levels around weaning, but the simultaneous higher $\mathrm{BW}$ in these calves was not considered when assessing SF intake. From wk 15 onward, the adaption to SF intake of $20 \%$-MR calves was apparently completed, as MEI/ $\mathrm{mBW}$ remained constant and did not differ relative to the $10 \%$-MR group.

The higher $\mathrm{MEI} / \mathrm{mBW}$ in 20\%-MR animals preweaning also resulted in a higher ADG before weaning, which was accompanied with higher $\mathrm{mBW}, \mathrm{BFT}$, and $\mathrm{MD}$ levels. Interestingly, the drop in $\mathrm{MEI} / \mathrm{mBW}$ around weaning was not reflected by a drop in ADG, which contrasts earlier studies reporting decelerated growth of high versus low MFI calves (approximately 1.00-1.12 vs. $0.68-0.75 \mathrm{~kg}$ of solids/d with varying fat and $\mathrm{CP}$ contents) during the weaning (Bach et al., 2013) or early postweaning period (Hill et al., 2010). However, the BFT and MD development of the $20 \%$-MR animals stagnated during weaning. This data suggests a proportionally higher gut fill with SF in $20 \%$-MR animals during the weaning period from which the animals took no advantage to gain body condition. Over the course of the postweaning period body condition differences between feeding groups ceased despite continuing but decreasing differences in $\mathrm{mBW}$. This points to a decelerated feed use efficiency in $20 \%$-MR fed calves, compensatory growth in 10\%-MR fed calves, or both.

Prolonged MR feeding (Meale et al., 2015; Schwarzkopf et al., 2019) and gradual weaning (Steele et al.,

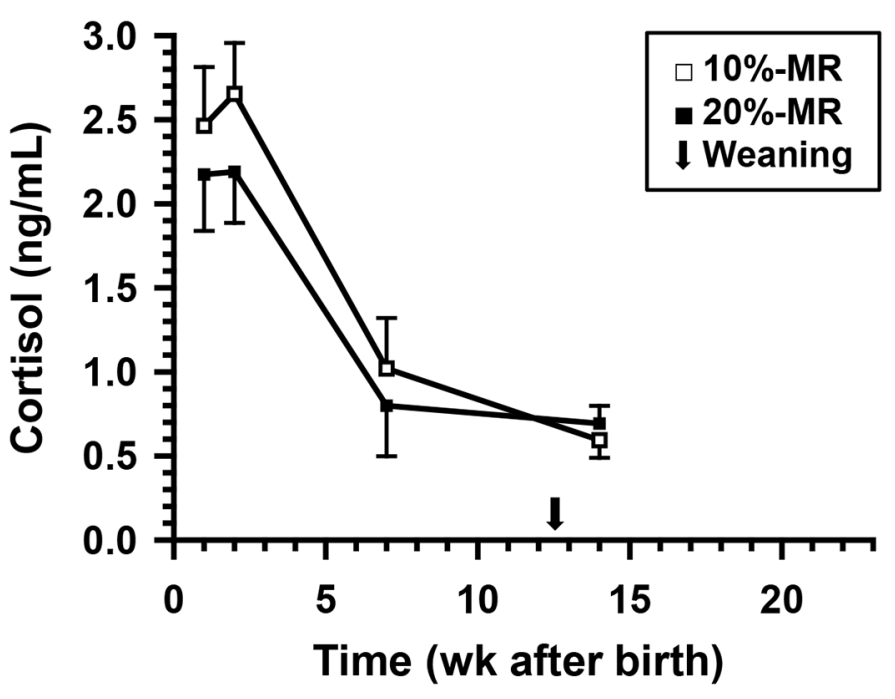

Figure 5. Salivary concentrations of cortisol in calves fed milk replacer (MR) at a rate of either $10 \%$ ( $\square 10 \%$-MR) or $20 \%$ ( $20 \%$-MR) of BW. Arrow indicates completed weaning. Data are shown as LSM \pm SE. $P_{\text {MR-rate }}=0.30, P_{\text {time }}<0.001, P_{\text {MR-ratextime }}=0.60$. The $P$-values of the fixed effects of cannula, MR-rate $\times$ cannula, and MR-rate $\times$ cannula $\times$ time are presented in Supplemental Table S9 (https://doi .org/10.5281/zenodo.4881616). 
2017) support calves to maintain growth rates, and gradual weaning also has a positive effect on starter consumption (Steele et al., 2017; Klopp et al., 2019) of calves fed elevated MR rates at solids up to approximately 1.14 to $1.35 \mathrm{~kg} / \mathrm{d}$. Nevertheless, even our prolonged MR feeding until wk 12 combined with gradual weaning over 4 wk could not completely prevent performance impairment during weaning in $20 \%$-MR fed calves. Yet, 20\%-MR calves were able to maintain their advantage in mBW of $6 \mathrm{~kg}^{0.75}$ shortly after weaning to still $4.5 \mathrm{~kg}^{0.75}$ in wk 23 .

\section{Energy Conversion Efficiency}

Among others, feed efficiency can be expressed as feed conversion ratio, which is weight gain relative to feed intake. This term, however, is not suitable to compare feed efficiencies of calves fed different MR levels as it does not account for the higher digestibility and energy density of MR compared with starter or SF. Therefore, we assessed efficiency based on the gain to MEI ratio. The respective ECR was not different between our experimental groups when analyzed on a weekly basis (Figure 1d). But when analyzed for the whole weaning and postweaning period (Table 1), ECR was lower in $20 \%$-MR compared with 10\%-MR calves. This agrees to previous findings demonstrating that ECR around or after weaning was lower in calves fed MR rates up to approximately 0.92 to $1.39 \mathrm{~kg}$ of DM/d compared with 0.64 to $0.7 \mathrm{~kg}$ of DM/d (Dennis et al., 2017; Hu et al., 2020; van Niekerk et al., 2020). The postweaning lower ECR in calves fed high MFI could have been because heavier animals with a higher $\mathrm{mBW}$ require more energy for maintenance, and therefore, have less energy available for growth. To test if feeding groups have a similar ECR at the same $\mathrm{mBW}$, we performed a regression analysis, revealing that the slope and intersection were not different between groups. Conclusively, the difference in $\mathrm{mBW}$ may explain the difference in ECR between feeding groups postweaning. The lower ECR can also be attributed to reduced energy availability through delayed rumen development and reduced digestibility of SF, as often observed in calves fed high MFI (Khan et al., 2011b).

\section{Metabolic Heat Production, Carbohydrate, and Fat Oxidation}

The higher $\mathrm{mBW}$ along with the higher MEI is reflected by a higher total HP in 20\%-MR group. However, despite the higher $\mathrm{MEI} / \mathrm{mBW}$ of $20 \%$-MR calves in wk 6 and 9, HP/mBW was higher only in wk 6 but not in wk 9, although $\mathrm{HP} / \mathrm{BW}^{0.85}$ typically increases with increasing feeding level in milk-fed veal calves (Labussière et al., 2009b). This is owed to the difference in $\mathrm{MEI} / \mathrm{mBW}$ between our groups amounting to $0.32 \mathrm{MJ} /$ $\mathrm{kg}^{0.75}$ in wk 6 but only to $0.11 \mathrm{MJ} / \mathrm{kg}^{0.75}$ in wk 9. The smaller difference in wk 9 can be attributed to the start of the weaning period when $\mathrm{MEI} / \mathrm{mBW}$ declines from wk 8 to 9 in 20\%-MR calves.

The HP/MEI was higher in the $10 \%$-MR group but again only in wk 6. Labussière et al. (2009b) also reported that HP as percentage of MEI decreases with increasing milk feeding levels in veal calves. This is most likely due to an insufficient supply of total MEI in $10 \%$-MR animals, resulting in a higher portion of MEI burned in favor of maintenance requirements. However, estimation of efficiency by the HP/MEI quotient does not take into account that $10 \%$-MR animals were also lighter, and therefore, had lower maintenance requirements than 20\%-MR animals. Also, the actual ME available might be overestimated (Quigley et al., 2019) as discussed above, especially in the $10 \%$-MR group. Therefore, the actual HP/MEI in 10\%-MR animals might have been even higher than calculated in the present study. In conclusion, apart from a possible higher portion of MEI used for maintenance requirements, the higher HP/MEI in the 10\%-MR group in wk 6 indicates lower metabolic efficiency in these calves. This conclusion is supported by an earlier study showing that veal calves offered the higher SF level in addition to MR feeding had a lower efficiency for utilizing ME for maintenance and growth along with an increased thermic effect of feeding and greater urinary $\mathrm{N}$ excretion than their counterparts (Labussière et al., 2009a). This effect was explained by higher energy requirements of the digestive tract at higher SF intake levels (Labussière et al., 2009a) and greater HP from protein compared with carbohydrate or lipid catabolism (Armstrong, 1969). A higher $\mathrm{N}$ catabolism was also observed in 10\%-MR fed animals from wk 2 to 5 as indicated by the higher plasma urea concentrations in this group.

Maintenance energy requirements increase with mBW (NRC, 2001) and feeding level (Labussière et al., 2011), and accordingly COX and FOX were higher in $20 \%$ than 10\%-MR calves before weaning. Group differences between COX and FOX vanished postweaning, likely because the difference in MEI ceased in parallel. Accordingly, COX/MEI and FOX/MEI were not different between feeding groups, suggesting comparable dietary use efficiencies and use preferences of related macronutrients in both feeding groups. In contrast, van den Borne et al. (2007) have shown that dietary glucose is almost completely oxidized in calves regardless of the feeding level and excess of dietary fat is stored as body fat rather than oxidized. Similarly Gerrits (2019) 
reported that the percentage of dietary fatty acids oxidized in calves decreases from almost $80 \%$ to about $30 \%$ as feed intake increases from 1.5 to 2.5 the ME requirements for maintenance. The latter is not supported by our finding of similar FOX/MEI and COX/ MEI between feeding groups. On the other hand, COX/ MEI and $\mathrm{RQ}_{\text {metab }}$ increased over time simultaneously with plasma BHB levels, demonstrating the increasing dominance of carbohydrates as a major fuel with age in both groups. Interestingly, the metabolic capacity for generating energy from carbohydrates was developed earlier in $20 \%$-MR calves as it can be seen from the higher COX $/ \mathrm{mBW}$ in $20 \%$ relative to $10 \%$-MR calves in wk 6 . Moreover, the lower $\mathrm{COX} / \mathrm{mBW}$ of $10 \% \mathrm{MR}$ fed calves indicates insufficient metabolic capacity for oxidizing carbohydrates despite of their greater $\mathrm{SF}$ intake in wk 6. On the other hand, a higher ME and potentially higher glucose availability in the $20 \%$ MR group, as reflected by the higher plasma glucose concentrations, could have also led to a higher COX/ $\mathrm{mBW}$ in these calves, which the $10 \%$-MR group could not compensate for despite higher SF intake. This is in line with van den Borne et al. (2007), who reported that glucose is the primary energy source in preweaning calves.

To account for the inconsistent differences in MEI as well as $\mathrm{mBW}$, and thus, in maintenance requirements between groups, COX, FOX, and HP were normalized to both MEI and $\mathrm{mBW}$. This approach identifies the amount of heat or macronutrients that 1 unit of $\mathrm{mBW}$ produces or converts from $1 \mathrm{MJ}$ of $\mathrm{ME}$ ingested. Overall, $1 \mathrm{~kg} \mathrm{mBW}$ of 20\%-MR calves oxidized less carbohydrates in wk 9 , tended to oxidize less fat at least in wk 6, and produced less heat from 1 MJ MEI, pointing to a higher metabolic efficiency in these animals. The results are comparable to those for HP/MEI discussed above. Yet, double normalization by MEI and $\mathrm{mBW}$ is a better indicator of efficiency than HP/MEI, because it accounts for the different maintenance requirements by including $\mathrm{mBW}$. On the other hand, maintenance requirements are not exclusively dependent on $\mathrm{mBW}$ but additionally increase with increasing feeding level (Labussière et al., 2011), indicating that even double normalization has its limits in assessing metabolic efficiencies. However, as the group, differences in HP disappeared in wk 15 to 22 , it seems unlikely that metabolic efficiency influences milk yield later in life as described by Soberon and Van Amburgh (2013) and thus, cannot be the reason for divergent metabolic efficient phenotypes described for first lactating dairy cows (Derno et al., 2019).

Due to their lower MR allowance, 10\%-MR calves were in lower EB in wk 6 and 9 than 20\%-MR fed calves. More specifically, the average EB of the $10 \%$-MR fed animals in wk 6 was $2.1 \mathrm{MJ}$, which is very close to zero, thus highlighting the potential of undernutrition in at least some of the animals in this group. Therefore, restricted feeding of only $10 \% \mathrm{MR}$ of $\mathrm{BW}$ despite provision of SF for ad libitum intake is hardly tolerable, not only in terms of animal welfare (Costa et al., 2019), but also for meeting the energy and nutritional requirements of growing calves. It should be noted, however, that EB may be particularly low in $10 \%$-MR calves because hay was offered unlimited. Detrimental effects of preweaning high forage feeding may include lower intake of the more energy-dense starter leading to reduced growth as described in the review by Xiao et al. (2020). This effect might have occurred in our restrictively fed animals when they compensated for the lower MR allowance. On the other hand, calves fed higher milk rates of $8 \mathrm{~L} / \mathrm{d}$ appear to benefit from forage supply as indicated by their improved solid feed intake and reticulorumen growth (Khan et al., 2011a). Although the positive effects of forage feeding depend on many factors, it has generally been shown to have a positive effect on eating and rumination behavior and a more stable ruminal environment (Xiao et al., 2020).

\section{Plasma Metabolites and Salivary Cortisol}

A positive relationship usually exists between protein intake and plasma or serum urea concentration of calves (Blome et al., 2003; Quigley et al., 2006; Hill et al., 2010). Accordingly, higher plasma urea concentrations were observed in 20\%-MR fed calves in wk 9. However, in a few cases, a restricted MFI in calves also resulted in higher serum or plasma urea concentrations before weaning, for example, when comparing MR (on the DM basis) feeding rates of 1.25 with $1.75 \%$ of BW/d (Bartlett et al., 2006), MR intakes of approximately 0.48 versus $1.26 \mathrm{~kg} / \mathrm{d}$ (Terre et al., 2009), or daily MR feeding rates of solids at approximately $0.75 \mathrm{~kg} / \mathrm{d}$ compared with ad libitum feeding (Schäff et al., 2016). A comparable result was obtained from the present study in the early preweaning period. Increased urea concentrations can be attributed to prevailing protein catabolism which likely occurs to meet the energy requirements during restrictive MR feeding.

Salivary cortisol concentrations decreased after d 8 in both groups, which was similar to reported plasma cortisol concentrations in the study by Frieten et al. (2017), comparing MR feeding rates of solids at approximately $0.75 \mathrm{~kg} / \mathrm{d}$ with ad libitum feeding. Although Frieten et al. (2017) observed higher plasma cortisol concentrations in restrictively fed calves preweaning, our MR feeding groups exhibited comparable 
salivary cortisol concentrations. This is probably owed to the high variability, affecting the at least numerically higher salivary cortisol concentrations in pre-weaned $10 \%$-MR fed animals. Elevated cortisol levels stimulate proteolytic processes (Bassett, 1968; Ndibualonji et al., 1995 ) and would thereby correspond to the preweaning increased protein catabolism in animals fed 10\%-MR.

Further analyzed plasma metabolites also varied between the feeding groups mainly preweaning due to the different MR allowances. In line with previous studies, temporarily higher glucose and TG concentrations were observed with an intensified MR feeding rate of solids at approximately $0.75 \mathrm{~kg} / \mathrm{d}$ relative to ad libitum feeding (Schäff et al., 2016; Frieten et al., 2017). Plasma BHB concentrations, an indicator of rumen development and starter intake, increase with SF intake (Deelen et al., 2016) and accordingly BHB paralleled SF intake in our study (Tümmler et al., 2020). The higher plasma NEFA concentrations in 10\%-MR calves preweaning in wk 2 are in parallel with the findings of Schäff et al. (2016) and Frieten et al. (2017), who compared MR feeding rates of solids at approximately $0.75 \mathrm{~kg} / \mathrm{d}$ with ad libitum feeding. These results mirror the lower EB due to restricted MR feeding. The lower plasma NEFA concentrations in the 10\%-MR group in wk 5 and 9 may be caused by a lower uptake of fatty acids with MR, as proposed by Schwarzkopf et al. (2019).

In the postweaning period, the plasma metabolite concentrations are less consistent with previous literature. Khan et al. (2007a) did not observe differences after weaning in calves fed different MFI in plasma TG concentrations (e.g., when milk feeding rates of $10 \%$ versus up to $20 \%$ of BW were compared). Furthermore, no differences in plasma glucose concentrations were found between calves fed MR feeding rates (on DM basis, varying fat and $\mathrm{CP}$ contents) at $0.45,0.67$, and $0.89 \mathrm{~kg} / \mathrm{d}$ (Chapman et al., 2017) or at approximately $0.75 \mathrm{~kg} / \mathrm{d}$ versus ad libitum feeding (Kesser et al., 2017). However, we observed temporally higher glucose, TG, and BHB concentrations in 10\%-MR fed animals at the end of the experimental period. The reason for this discrepancy remains unclear but might be owed to the numerically higher $\mathrm{MEI} / \mathrm{mBW}$ ratio in $10 \%$-MR animals after weaning.

\section{Effect of Colostrum Intake}

The influence of the colostrum allowance $(10 \%$ of BW for $10 \%$-MR group vs. $12 \%$ of BW for $20 \%$-MR group) cannot be distinguished from the influence of the MFI. An elevated plane of colostrum feeding can improve growth and feed efficiency in calves (Kargar et al., 2020) potentially through its bioactive components. The colostrum intake of calves can also affect the intestinal morphology and digestive enzyme activities (Blättler et al., 2001), the expression of neuroendocrine genes (Hromádková et al., 2020), as well as metabolic and endocrine status (Kühne et al., 2000; Rauprich et al., 2000; Hammon et al., 2013). In this respect, all observed effects of MFI on growth performance and energy metabolism may also have been influenced or caused by colostrum intake. However, because the difference in colostrum intake is quite small and our observations are consistent with studies that investigated only the influence of MFI, we assume that MFI is the main factor influencing the group differences observed in the present study. In addition, the colostrum pools fed in this study originated from farms from which none of the calves originated, indicating that all calves experienced comparable immunization with colostrum intake.

\section{CONCLUSIONS}

During the preweaning period, the higher MEI with the higher MR feeding level induced higher gain of BW and body condition, improved EB, and thus, increased metabolic HP of dairy calves. The observation that 1 $\mathrm{kg}$ of metabolic BW oxidized less carbohydrates and produced less heat from 1 MJ metabolizable energy indicates that calves fed a higher plane of MR before weaning are metabolically more efficient than calves fed MR restrictively. Vice versa, calves fed MR restrictively are metabolically less efficient as they rely on a higher protein catabolism, thereby losing more metabolic heat per unit of MEI. After weaning, the effect of an elevated liquid feeding intensity on the energy use efficiency estimates vanished, and thus, cannot be recognized as factor determining metabolic efficiency later in life. However, some uncertainty remains in comparing energy use efficiencies of the 2 groups because the proportion of ME intake used for maintenance could only be estimated. The apparently negative effect of an increased liquid feeding intensity on the postweaning $\mathrm{ECR}$ is due to the higher postweaning $\mathrm{mBW}$, and thus, higher maintenance requirements of these calves.

\section{ACKNOWLEDGMENTS}

We gratefully thank H. Brandt, C. Arlt, R. Fürstenberg, P. Müntzel, E.-A. Paetow, M. Gnott, J. Rischewski, C. Mueller, and the staff at the "Tiertechnikum" and the Experimental Animal Facility Cattle at the FBN, Dummerstorf, Germany, for assistance in respiration chamber measurements, cannula manufacturing, animal care and handling, sample collection, and sample preparation. We further thank Dr K. M. Kennedy for English editing. Publication of this article was 
funded by the Open Access Fund of the FBN. This work was conducted in frame of the JPI FACCE program and financially supported by the German Federal Ministry of Food and Agriculture (BMEL) through the Federal Office for Agriculture and Food (BLE), grant number 2814ERA04A. Data are stored at FBN and are available on request. The authors declare no conflict of interest.

\section{REFERENCES}

Armstrong, D. G. 1969. Cell bioenergetics and energy metabolism. Pages 385-414 in Handbuch der Tierernährung. Vol. 1. W. Lenkeit, K. Breikem, and E. Crasemann, ed. Parey.

Bach, A., M. Terré, and A. Pinto. 2013. Performance and health responses of dairy calves offered different milk replacer allowances. J. Dairy Sci. 96:7790-7797. https://doi.org/10.3168/jds.2013-6909.

Bartlett, K. S., F. K. McKeith, M. J. VandeHaar, G. E. Dahl, and J. K. Drackley. 2006. Growth and body composition of dairy calves fed milk replacers containing different amounts of protein at two feeding rates. J. Anim. Sci. 84:1454-1467. https://doi.org/10 $.2527 / 2006.8461454 x$.

Bassett, J. M. 1968. The relation of fat and protein catabolic actions of cortisol to glucose homeostasis in fasting sheep. Metabolism 17:644-652. https://doi.org/10.1016/0026-0495(68)90024-3.

Blättler, U., H. M. Hammon, C. Morel, C. Philipona, A. Rauprich, V. Romé, I. Le Huërou-Luron, P. Guilloteau, and J. W. Blum. 2001. Feeding colostrum, its composition and feeding duration variably modify proliferation and morphology of the intestine and digestive enzyme activities of neonatal calves. J. Nutr. 131:1256-1263. https://doi.org/10.1093/jn/131.4.1256.

Blome, R. M., J. K. Drackley, F. K. McKeith, M. F. Hutjens, and G. C. McCoy. 2003. Growth, nutrient utilization, and body composition of dairy calves fed milk replacers containing different amounts of protein. J. Anim. Sci. 81:1641-1655. https://doi.org/10.2527/ 2003.8161641x.

Broesder, J. T., M. B. Judkins, L. J. Krysl, S. A. Gunter, and R. K. Barton. 1990. Thirty or sixty percent milk replacer reduction for calves: Effects on alfalfa hay intake and digestibility, digestive kinetics and ruminal fermentation. J. Anim. Sci. 68:2974-2985. https://doi.org/10.2527/1990.6892974x.

Brouwer, E. 1965. Report of sub-committee on constants and factors. in Proc. of the 3rd Symposium on Energy Metabolism in Troon, UK. Academic Press.

Bruckmaier, R. M., E. Lehmann, D. Hugi, H. M. Hammon, and J. W. Blum. 1998. Ultrasonic measurement of longissimus dorsi muscle and backfat, associated with metabolic and endocrine traits, during fattening of intact and castrated male cattle. Livest. Prod. Sci. 53:123-134. https://doi.org/10.1016/S0301-6226(97)00162-0.

Chapman, C. E., P. S. Erickson, J. D. Quigley, T. M. Hill, H. G. Bateman II, F. X. Suarez-Mena, and R. L. Schlotterbeck. 2016. Effect of milk replacer program on calf performance and digestion of nutrients with age of the dairy calf. J. Dairy Sci. 99:2740-2747. https://doi.org/10.3168/jds.2015-10372.

Chapman, C. E., T. M. Hill, D. R. Elder, and P. S. Erickson. 2017. Nitrogen utilization, preweaning nutrient digestibility, and growth effects of Holstein dairy calves fed 2 amounts of a moderately high protein or conventional milk replacer. J. Dairy Sci. 100:279-292. https://doi.org/10.3168/jds.2016-11886.

Chwalibog, A., K. Jensen, and G. Thorbek. 1996. Oxidation of nutrients in bull calves treated with beta-adrenergic agonists. Arch. Tierernahr. 49:255-261. https://doi.org/10.1080/17450399609381888.

Costa, J. H. C., M. C. Cantor, N. A. Adderley, and H. W. Neave. 2019. Key animal welfare issues in commercially raised dairy calves: Social environment, nutrition, and painful procedures. Can. J. Anim. Sci. 99:649-660. https://doi.org/10.1139/cjas-2019-0031.

Deelen, S. M., K. E. Leslie, M. A. Steele, E. Eckert, H. E. Brown, and T. J. DeVries. 2016. Validation of a calf-side beta-hydroxybutyrate test and its utility for estimation of starter intake in dairy calves around weaning. J. Dairy Sci. 99:7624-7633. https://doi.org/10 $.3168 /$ jds.2016-11097.

Dennis, T. S., F. X. Suarez-Mena, T. M. Hill, J. D. Quigley, and R. L. Schlotterbeck. 2017. Effects of egg yolk inclusion, milk replacer feeding rate, and low-starch (pelleted) or high-starch (texturized) starter on Holstein calf performance through 4 months of age. J. Dairy Sci. 100:8995-9006. https://doi.org/10.3168/jds.2017-13169.

Derno, M., H. G. Elsner, E. A. Paetow, H. Scholze, and M. Schweigel. 2009. Technical note: A new facility for continuous respiration measurements in lactating cows. J. Dairy Sci. 92:2804-2808. https: //doi.org/10.3168/jds.2008-1839.

Derno, M., G. Nürnberg, and B. Kuhla. 2019. Characterizing the metabotype and its persistency in lactating Holstein cows: An approach toward metabolic efficiency measures. J. Dairy Sci. 102:6559-6570. https://doi.org/10.3168/jds.2019-16274.

Derno, M., G. Nürnberg, P. Schön, A. Schwarm, M. Röntgen, H. M. Hammon, C. C. Metges, R. M. Bruckmaier, and B. Kuhla. 2013. Short-term feed intake is regulated by macronutrient oxidation in lactating Holstein cows. J. Dairy Sci. 96:971-980. https://doi.org/ $10.3168 /$ jds. 2012-5727.

Eckert, E., H. E. Brown, K. E. Leslie, T. J. DeVries, and M. A. Steele 2015. Weaning age affects growth, feed intake, gastrointestinal development, and behavior in Holstein calves fed an elevated plane of nutrition during the preweaning stage. J. Dairy Sci. 98:6315-6326. https://doi.org/10.3168/jds.2014-9062.

Frieten, D., C. Gerbert, C. Koch, G. Dusel, K. Eder, E. Kanitz, J. M. Weitzel, and H. M. Hammon. 2017. Ad libitum milk replacer feeding, but not butyrate supplementation, affects growth performance as well as metabolic and endocrine traits in Holstein calves. J. Dairy Sci. 100:6648-6661. https://doi.org/10.3168/jds.2017-12722.

Gelsinger, S. L., A. J. Heinrichs, and C. M. Jones. 2016. A metaanalysis of the effects of preweaned calf nutrition and growth on first-lactation performance. J. Dairy Sci. 99:6206-6214. https:// doi.org/10.3168/jds.2015-10744.

Gerrits, W. J. J. 2019. Symposium review: Macronutrient metabolism in the growing calf. J. Dairy Sci. 102:3684-3691. https://doi.org/ $10.3168 / j d s .2018-15261$.

GfE (German Society of Nutrition Physiology). 2004. Schätzung des Gehaltes an Umsetzbarer Energie in Mischrationen (TMR) für Wiederkäuer. Pages 195-198 in Proc. of the Society of Nutrition Physiology. DLG-Verlag, Göttingen.

GfE (German Society of Nutrition Physiology) 2008. New Equations for Predicting Metabolisable Energy of Grass and Maize Products for Ruminants. Pages 191-198 in Proc. of the Society of Nutrition Physiology. DLG-Verlag, Göttingen.

GfE (German Society of Nutrition Physiology) 2009. New Equations for Predicting Metabolisable Energy of Compound Feeds for Cattle. Pages 143-146 in Proc. of the Society of Nutrition Physiology. DLG-Verlag, Göttingen.

Hammon, H. M., W. Liermann, D. Frieten, and C. Koch. 2020. Review: Importance of colostrum supply and milk feeding intensity on gastrointestinal and systemic development in calves. Animal 14:s133-s143. https://doi.org/10.1017/S1751731119003148.

Hammon, H. M., J. Steinhoff-Wagner, J. Flor, U. Schönhusen, and C. C. Metges. 2013. Lactation Biology Symposium: Role of colostrum and colostrum components on glucose metabolism in neonatal calves. J. Anim. Sci. 91:685-695. https://doi.org/10.2527/jas .2012-5758.

Hill, T. M., H. G. Bateman II, J. M. Aldrich, and R. L. Schlotterbeck. 2010. Effect of milk replacer program on digestion of nutrients in dairy calves. J. Dairy Sci. 93:1105-1115. https://doi.org/10.3168/ jds.2009-2458.

Hromádková, J., Y. Suzuki, S. Pletts, J. Pyo, T. Ma, Y. Chen, M. A. Steele, and L. L. Guan. 2020. Effect of colostrum feeding strategies on the expression of neuroendocrine genes and active gut mucosaattached bacterial populations in neonatal calves. J. Dairy Sci. 103:8629-8642. https://doi.org/10.3168/jds.2019-17710.

Hu, W., T. M. Hill, T. S. Dennis, F. X. Suarez-Mena, K. M. Aragona, J. D. Quigley, and R. L. Schlotterbeck. 2020. Effects of milk replacer feeding rates on growth performance of Holstein dairy calves 
to 4 months of age, evaluated via a meta-analytical approach. J. Dairy Sci. 103:2217-2232. https://doi.org/10.3168/jds.2019-17206.

Hu, W., T. M. Hill, T. S. Dennis, F. X. Suarez-Mena, J. D. Quigley, and R. L. Schlotterbeck. 2019. Intake, nutrient digestibility, and growth performance of Holstein dairy calves consuming a milk replacer at moderate or high feeding rates. J. Dairy Sci. 102:79177926. https://doi.org/10.3168/jds.2019-16282.

Jasper, J., and D. M. Weary. 2002. Effects of ad libitum milk intake on dairy calves. J. Dairy Sci. 85:3054-3058. https://doi.org/10.3168/ jds.S0022-0302(02)74391-9.

Jentsch, W., M. Beyer, M. Derno, and H. Franz. 1996. Untersuchungen zum Energie- und Stickstoffumsatz von Kälbern bei unterschiedlichen Umgebungstemperaturen. Arch. Tierz. 39:571-587.

Kargar, S., M. Roshan, S. M. Ghoreishi, A. Akhlaghi, M. Kanani, A. R. Abedi Shams-Abadi, and M. H. Ghaffari. 2020. Extended colostrum feeding for 2 weeks improves growth performance and reduces the susceptibility to diarrhea and pneumonia in neonatal Holstein dairy calves. J. Dairy Sci. 103:8130-8142. https://doi .org/10.3168/jds.2020-18355.

Kenéz, Á., C. Koch, M. Korst, J. Kesser, K. Eder, H. Sauerwein, and K. Huber. 2018. Different milk feeding intensities during the first 4 weeks of rearing dairy calves: Part 3: Plasma metabolomics analysis reveals long-term metabolic imprinting in Holstein heifers. J. Dairy Sci. 101:8446-8460. https://doi.org/10.3168/jds.2018-14559.

Kertz, A. F., T. M. Hill, J. D. Quigley 3rd, A. J. Heinrichs, J. G. Linn, and J. K. Drackley. 2017. A 100-year review: Calf nutrition and management. J. Dairy Sci. 100:10151-10172. https://doi.org/10 $.3168 /$ jds.2017-13062.

Kesser, J., M. Korst, C. Koch, F. J. Romberg, J. Rehage, U. Müller, M. Schmicke, K. Eder, H. M. Hammon, H. Sadri, and H. Sauerwein. 2017. Different milk feeding intensities during the first 4 weeks of rearing dairy calves: Part 2: Effects on the metabolic and endocrine status during calfhood and around the first lactation. J. Dairy Sci. 100:3109-3125. https://doi.org/10.3168/jds.2016-11595.

Khan, M. A., H. J. Lee, W. S. Lee, H. S. Kim, K. S. Ki, T. Y. Hur, G. H. Suh, S. J. Kang, and Y. J. Choi. 2007a. Structural growth, rumen development, and metabolic and immune responses of Holstein male calves fed milk through step-down and conventional methods. J. Dairy Sci. 90:3376-3387. https://doi.org/10.3168/jds .2007-0104.

Khan, M. A., H. J. Lee, W. S. Lee, H. S. Kim, S. B. Kim, K. S. Ki, J. K. Ha, H. G. Lee, and Y. J. Choi. 2007b. Pre- and postweaning performance of Holstein female calves fed milk through step-down and conventional methods. J. Dairy Sci. 90:876-885. https://doi .org/10.3168/jds.S0022-0302(07)71571-0.

Khan, M. A., D. M. Weary, and M. A. von Keyserlingk. 2011a. Hay intake improves performance and rumen development of calves fed higher quantities of milk. J. Dairy Sci. 94:3547-3553. https://doi .org/10.3168/jds.2010-3871.

Khan, M. A., D. M. Weary, and M. A. G. von Keyserlingk. 2011b. Invited review: Effects of milk ration on solid feed intake, weaning, and performance in dairy heifers. J. Dairy Sci. 94:1071-1081. https://doi.org/10.3168/jds.2010-3733.

Klopp, R. N., F. X. Suarez-Mena, T. S. Dennis, T. M. Hill, R. L. Schlotterbeck, and G. J. Lascano. 2019. Effects of feeding different amounts of milk replacer on growth performance and nutrient digestibility in Holstein calves to 2 months of age using different weaning strategies. J. Dairy Sci. 102:11040-11050. https://doi .org/10.3168/jds.2019-17153.

Kühne, S., H. M. Hammon, R. M. Bruckmaier, C. Morel, Y. Zbinden, and J. W. Blum. 2000. Growth performance, metabolic and endocrine traits, and absorptive capacity in neonatal calves fed either colostrum or milk replacer at two levels. J. Anim. Sci. 78:609-620. https://doi.org/10.2527/2000.783609x.

Labussiere, E., S. Dubois, J. van Milgen, G. Bertrand, and J. Noblet. 2009a. Effect of solid feed on energy and protein utilization in milk-fed veal calves. J. Anim. Sci. 87:1106-1119. https://doi.org/ 10.2527/jas.008-1318.

Labussiere, E., G. Maxin, S. Dubois, J. van Milgen, G. Bertrand, and J. Noblet. 2009b. Effect of feed intake on heat production and pro- tein and fat deposition in milk-fed veal calves. Animal 3:557-567. https://doi.org/10.1017/S1751731108003777.

Labussière, E., J. van Milgen, C. F. M. de Lange, and J. Noblet. 2011. Maintenance energy requirements of growing pigs and calves are influenced by feeding level. J. Nutr. 141:1855-1861. https://doi .org/10.3945/jn.111.141291.

Leal, L. N., J. M. Romao, G. J. Hooiveld, F. Soberon, H. Berends, M. V. Boekshoten, M. E. Van Amburgh, J. Martín-Tereso, and M. A. Steele. 2018. Nutrient supply alters transcriptome regulation in adipose tissue of pre-weaning Holstein calves. PLoS One 13:e0201929. https://doi.org/10.1371/journal.pone.0201929.

Leão, J. M., S. G. Coelho, F. S. Machado, R. A. Azevedo, J. A. M. Lima, J. C. Carneiro, C. F. A. Lage, A. L. Ferreira, L. G. R. Pereira, T. R. Tomich, and M. M. Campos. 2018. Phenotypically divergent classification of preweaned heifer calves for feed efficiency indexes and their correlations with heat production and thermography. J. Dairy Sci. 101:5060-5068. https://doi.org/10.3168/ jds.2017-14109.

Meale, S. J., L. N. Leal, J. Martín-Tereso, and M. A. Steele. 2015. Delayed weaning of Holstein bull calves fed an elevated plane of nutrition impacts feed intake, growth and potential markers of gastrointestinal development. Anim. Feed Sci. Technol. 209:268-273. https://doi.org/10.1016/j.anifeedsci.2015.08.008.

Naeem, A., J. K. Drackley, J. Stamey, and J. J. Loor. 2012. Role of metabolic and cellular proliferation genes in ruminal development in response to enhanced plane of nutrition in neonatal Holstein calves. J. Dairy Sci. 95:1807-1820. https://doi.org/10.3168/jds .2011-4709.

Ndibualonji, B. B., D. Dehareng, C. Van Eenaeme, and J. M. Godeau. 1995. Response of milk yield, plasma cortisol, amino acids, urea and glucose to a single low-dose administration of adrenocorticotrophic hormone in lactating cows. Vet. Res. 26:32-42.

NRC (National Research Council). 2001. Nutrient Requirements of Dairy Cattle. 7th. rev. ed. ed. The National Academies Press.

Quigley, J. D., W. Hu, J. R. Knapp, T. S. Dennis, F. X. Suarez-Mena, and T. M. Hill. 2019. Estimates of calf starter energy affected by consumption of nutrients. 2. Effect of changing digestion on energy content in calf starters. J. Dairy Sci. 102:2242-2253. https://doi .org/10.3168/jds.2018-15354.

Quigley, J. D., T. A. Wolfe, and T. H. Elsasser. 2006. Effects of additional milk replacer feeding on calf health, growth, and selected blood metabolites in calves. J. Dairy Sci. 89:207-216. https://doi .org/10.3168/jds.S0022-0302(06)72085-9.

Rauprich, A. B., H. M. Hammon, and J. W. Blum. 2000. Influence of feeding different amounts of first colostrum on metabolic, endocrine, and health status and on growth performance in neonatal calves. J. Anim. Sci. 78:896-908. https://doi.org/10.2527/2000 $.784896 \mathrm{x}$.

Schäff, C. T., J. Gruse, J. Maciej, M. Mielenz, E. Wirthgen, A. Hoeflich, M. Schmicke, R. Pfuhl, P. Jawor, T. Stefaniak, and H. M. Hammon. 2016. Effects of feeding milk replacer ad libitum or in restricted amounts for the first five weeks of life on the growth, metabolic adaptation, and immune status of newborn calves. PLoS One 11:e0168974. https://doi.org/10.1371/journal.pone.0168974.

Schröder, U. J., and R. Staufenbiel. 2006. Invited review: Methods to determine body fat reserves in the dairy cow with special regard to ultrasonographic measurement of backfat thickness. J. Dairy Sci. 89:1-14. https://doi.org/10.3168/jds.S0022-0302(06)72064-1.

Schwarzkopf, S., A. Kinoshita, J. Kluess, S. Kersten, U. Meyer, K. Huber, S. Dänicke, and J. Frahm. 2019. Weaning Holstein calves at 17 weeks of age enables smooth transition from liquid to solid feed. Animals (Basel) 9:1132. https://doi.org/10.3390/ani9121132.

Silva, A. L., T. J. DeVries, L. O. Tedeschi, and M. I. Marcondes. 2019. Development of equations, based on milk intake, to predict starter feed intake of preweaned dairy calves. Animal 13:83-89. https:// doi.org/10.1017/S1751731118000666.

Simonson, D. C., and R. A. DeFronzo. 1990. Indirect calorimetry: Methodological and interpretative problems. Am. J. Physiol. 258:E399-E412. https://doi.org/10.1152/ajpendo.1990.258.3 .E399. 
Soberon, F., and M. E. Van Amburgh. 2013. Lactation Biology Symposium: The effect of nutrient intake from milk or milk replacer of preweaned dairy calves on lactation milk yield as adults: A meta-analysis of current data. J. Anim. Sci. 91:706-712. https:// doi.org/10.2527/jas.2012-5834.

Steele, M. A., J. H. Doelman, L. N. Leal, F. Soberon, M. Carson, and J. A. Metcalf. 2017. Abrupt weaning reduces postweaning growth and is associated with alterations in gastrointestinal markers of development in dairy calves fed an elevated plane of nutrition during the preweaning period. J. Dairy Sci. 100:5390-5399. https:// doi.org/10.3168/jds.2016-12310.

Terré, M., C. Tejero, and A. Bach. 2009. Long-term effects on heifer performance of an enhanced-growth feeding programme applied during the preweaning period. J. Dairy Res. 76:331-339. https:// doi.org/10.1017/S0022029909004142.

Tümmler, L.-M., M. Derno, V. Röttgen, A. Vernunft, A. Tuchscherer, P. Wolf, and B. Kuhla. 2020. Effects of 2 colostrum and subsequent milk replacer feeding intensities on methane production, rumen development, and performance in young calves. J. Dairy Sci. 103:6054-6069. https://doi.org/10.3168/jds.2019-17875.

van den Borne, J. J. G. C., G. E. Lobley, M. W. A. Verstegen, J.M. Muijlaert, S. J. J. Alferink, and W. J. J. Gerrits, 2007. Body fat deposition does not originate from carbohydrates in milk-fed calves. J. Nutr. 137:2234-2241. https://doi.org/10.1093/jn/137.10 .2234 .

van Niekerk, J. K., A. J. Fischer-Tlustos, L. L. Deikun, J. D. Quigley, T. S. Dennis, F. X. Suarez-Mena, T. M. Hill, R. L. Schlotterbeck, L. L. Guan, and M. A. Steele. 2020. Effect of amount of milk replacer fed and the processing of corn in starter on growth performance, nutrient digestibility, and rumen and fecal fibrolytic bacteria of dairy calves. J. Dairy Sci. 103:2186-2199. https://doi .org/10.3168/jds.2019-17372.

Xiao, J., G. M. Alugongo, J. Li, Y. Wang, S. Li, and Z. Cao. 2020. Review: How forage feeding early in life influences the growth rate, ruminal environment, and the establishment of feeding behavior in pre-weaned calves. Animals (Basel) 10:188. https://doi.org/10 $.3390 /$ ani10020188

\section{ORCIDS}

Lisa-Maria Tümmler (ํ) https://orcid.org/0000-0002-4562-7777

Michael Derno ํ https://orcid.org/0000-0001-8932-2564

Björn Kuhla ๑ https://orcid.org/0000-0002-2032-5502 